\title{
Comparison of Higher Education Funding Systems between China and the United States
}

\author{
Xiaoqi Hu \\ School of Public Administration, Jinan University, Guangzhou, China \\ Email: hxq@stu2017.jnu.edu.cn
}

How to cite this paper: Hu, X.Q. (2019) Comparison of Higher Education Funding Systems between China and the United States. Open Journal of Social Sciences, 7, 150-159.

https://doi.org/10.4236/jss.2019.74013

Received: March 12, 2019

Accepted: April 13, 2019

Published: April 16, 2019

Copyright $\odot 2019$ by author(s) and Scientific Research Publishing Inc. This work is licensed under the Creative Commons Attribution International License (CC BY 4.0).

http://creativecommons.org/licenses/by/4.0/

(c) (i) Open Access

\begin{abstract}
In 2016, China's statistical bulletin on the development of education announced that the total amount of various types of higher education in China reached 36.99 million, and the gross enrollment rate of higher education reached $42.7 \%$. China is in a critical period from the popularization of higher education to the diffusion of higher education, and China's higher education has been developing rapidly. However, the problem of educational equity has been restricting the development of higher education in China. Poor students, in particular, are deeply affected by the problem. In order to help these students, it is an important way to establish and improve the higher education funding system. This paper first expounds the specific forms of the higher education funding system in China and the United States, then finds out the defects of the higher education funding system in China through the comparison between China and the United States, and tries to put forward some suggestions to better improve this shortcoming.
\end{abstract}

\section{Keywords}

Higher Education Funding System in China and the United States, Comparison of Higher Education Funding System, Recommendations for China's Higher Education Funding System

\section{Introduction}

In 2016, China's statistical bulletin on the development of education announced that the total amount of various types of higher education in China reached 36.99 million, and the gross enrollment rate of higher education reached $42.7 \%$. China is in a critical period from the popularization of higher education to the diffusion of higher education, and China's higher education has been developing rapidly. However, there are some restricting factors in the development process 
of higher education in China, such as the problem of educational equity. Poor students, in particular, are deeply affected by the problem of educational equity. In order to help poor students to solve their worries at home, it is an important way to establish and improve the higher education funding system.

The funding system for higher education in China is developing continuously. On March 1, 2019, the Ministry of Education of China announced that the total number of student aid in 2018 reached 135 million, with the amount of aid exceeding 200 billion yuan, an increase of more than $8 \%$. Since the 1970 s, the mode of "award, assistance, loan, reduction and subsidy" has been formed, and many poor students will not drop out of school due to economic difficulties. However, some problems still occur in the implementation process. The United States has many world-class universities, and its higher education is a model for other countries to learn from. Its higher education funding system also provides a platform for other countries to learn from. By studying and comparing the funding systems of China and the United States, we can better promote the improvement and development of China's funding system.

\section{Composition of the Higher Education Funding System in the United States}

The university funding policy of the United States consists of four parts: the federal government, the state government, universities and social organizations. The policy provides a certain degree of funding to eligible students through scholarships, grants, loans and study programs [1].

\subsection{Financial Aid}

1) The Pell Grants. In 1980, congress formally established the Pell Grant Program. The goal of Pell grants is to equalize educational opportunities, with undergraduates from low to middle income families being the main recipients. Pell grants are provided by the federal government. Students do not have to pay back, and each successful applicant receives $\$ 2775$ per semester.

2) Federal supplemental educational opportunity grants. This grant is for those who took part in the work-study or received Pell grants, but can't meet the needs of its economic aspects of undergraduate students, and will give priority to the students who received Pell grants, won the Pell grant students can also get Federal supplemental education opportunity grants, they are not in conflict. Federal supplemental education opportunity grants provide between $\$ 100$ and $\$ 4000$ per student per year, on average, and are funded by the US federal government.

\subsection{Student Loans}

1) Perkins loans. The loans are aimed at undergraduates or graduates from low-income families. Its operating procedure is for the federal government to grant loans to colleges and universities based on the application amount of each college, and then the colleges and universities to lend loans to students according to 
their applications. The interest on the perkins loan is first paid by the government. The interest rate is about 5 percent, the lowest of all the loans. Students start paying off loans ten months after graduation. After graduation, students can also apply for deferred repayment if they do not find a job immediately and their sources of income are limited. If after graduation to serve in the military or some social welfare undertakings, you can enjoy the preferential policy of loan forgiveness.

2) Student parent loans. The federal government provides loans to families with children in higher education who cannot afford it and whose parents have good credit histories. The loan amount cannot exceed the difference between the cost of a student's education and what the family can afford, and the interest rate on the loan is around $8 \%$.

3) Stafford loan. Formerly known as "national guaranteed loan", students in financial difficulties are the main target of this kind of loan. The loan funds are provided by commercial Banks, and the state government where the students are located provides credit guarantee. The loan amount increases with the growth of the freshman year to the graduate year, and the loan term is long and the interest is low. This loan is divided into Interest-free loans and interest-bearing loan. The US government provides that students who apply for a Interest-free loans can be exempted from interest charges if they apply for repayment during their studies or within six months of graduation, but students who apply for a Interest-free loan can borrow less than a interest-bearing loan [2].

\subsection{The Scholarship}

This kind of scholarship refers to the non-service labor scholarship, mainly based on academic performance ranking, and is free financial aid. The scholarship includes a national science scholarship, etc.

\subsection{Campus Work Scheme}

It mainly refers to the service labor scholarship, in which students get a certain amount of free remuneration by undertaking the labor work such as teaching assistant, financial aid and management assistance.

\section{Composition of the Higher Education Funding System in China}

China's higher education funding system has formed a five-in-one model of "award, assistance, loan, reduction and subsidy", which includes the following:

\subsection{The Scholarship}

The scholarships are divided into university scholarships, national encouragement scholarships and national scholarships.

1) University scholarship. This kind of scholarship is for the class in the comprehensive result outstanding student, it aims to encourage everybody to study own specialty well, participates in each kind of activity actively. Its fund source is 
each colleges and universities, because this its subsidize cost inspect a college and different, but its cost divides 3 levels commonly, occupy class to control $20 \%$.

2) National encouragement scholarship. This kind of scholarship is applicable to all undergraduate students of full-time colleges and universities (including higher vocational and second bachelor degree), and should meet the standards of excellent character and learning and family economic difficulties, its support face is all in school about $3 \%$, each person can get 5000 yuan every year. Within one academic year, the same student cannot receive both the national encouragement scholarship and the national scholarship. The main body of this kind of scholarship is coordinated by the central and local governments. The general application condition is that students who have won two school scholarships in a row in a school year and whose families have difficulties. The scholarship is evaluated once a year.

3) National scholarship. This kind of scholarship is also applicable to all undergraduate students of full-time colleges and universities (including higher vocational and second bachelor degree), and they need to meet the requirements of excellent comprehensive performance. Every year, 50,000 students in China can get this award, 8000 yuan per person per year. This scholarship is directly by the central government funding, object for the synthesis of the best students, general application conditions is obtained many times the school scholarships, outstanding students or honorary titles such as outstanding class cadre, when two conditions are met, students with provincial or national honors are preferred, the appraisal once a year.

\subsection{Financial Aid}

This kind of bursary is aimed at the full-time undergraduate and junior college students (including higher vocational education and second bachelor's degree) whose families are in financial difficulties, and the government allocates the subsidy funds. Students from poor families can apply for the grant, which is about $20 \%$ of the total number of students in school, and the grant is free of charge. The amount of subsidy is generally determined as three levels: the students who get the first grade are 4000 yuan per year, the students who get the second grade are 3000 yuan per year, and the students who get the third grade are 2000 yuan per year.

\subsection{Nation Student Loan}

The audience of the loan is family economic difficulties students, and the loan is dominated by the government, credit loans provided by financial institutions, students who apply for this kind of loan do not need to provide any guarantee or mortgage, the goal is to relieve the pressure on students in terms of tuition and accommodation, in general, each student loan amount must not exceed 8000 yuan per year, 20 years domestic demand pay off all loans. The lending rate is in line with the benchmark interest rate announced by the people's bank of China 
during the same period, and does not rise. The government helps the students to repay all the interest expenses generated during the period of study by means of interest discount. The interest generated after graduation is reimbursed independently by the students themselves, and the principal is repaid according to the agreement. There are two forms of state student loan: the first is the campus state student loan, which is to apply to the bank through the school. the second kind is the source of students credit student loans, that is, to the county (city, district) where the household registration of the student financial institutions to apply for. Among them, "the source of students credit student loans" are the most widely implemented and cover the largest number of poor people.

\subsection{Tuition Waiver}

Tuition fee remission is divided into full reduction and half reduction, and the target of the subsidy is mainly for poor students' families such as parents' casualties, parents' disabilities or single parents.

\subsection{Hardship Grants and Work-Study Grants}

Hardship grants is provided to students from poor families by governments at all levels. It is a kind of temporary free subsidy, such as giving quilts to students with difficulties in winter. Work-study grants is an opportunity for the school to provide some on-campus and off-campus work-study positions for students free of charge, and priority should be given to students from poor families. According to the regulation, the time spent on work-study cannot exceed 8 hours per week and 40 hours per month, and the labor remuneration should not be lower than the minimum wage standard set by the local government in principle.

In addition, there are normal university students free education, green channel and other forms of funding.

\section{Comparison of Higher Education Funding Systems between China and the United States}

\subsection{The Similarities}

1) Funding targets and goals are similar. In the United States, direct federal grants to students with financial difficulties are designed to help children of low-income families attend school. But our country financial aid object also is mainly aims at the family financial difficulty student but establishes [3]. At the same time, both China and the United States carry out higher education funding policies for the purpose of better promoting educational equity and helping every student to enjoy the same educational opportunities.

2) Funding comes in many forms. Both China and the United States have higher education funding systems in the form of grants, grants, student loans and other forms of diversification to increase the coverage and breadth of beneficiaries.

3) Funding policies are valued. Both the US government and the Chinese government have recognized the importance of the funding policies. The funding 
policies of the two countries have been concerned by the government from the beginning to the present, from the narrow to the wide, and from the lack to the continuous improvement of the funding system.

\subsection{The Differences}

1) The subjects of funding are different. The funding subjects in the United States are diverse, including government, universities, social participation and enterprises, and each of them has played an important role. In the United States, 44 percent of grants come from the federal government, 9 percent from state governments, 33 percent from colleges, and 10 percent from private organizations [4]. The funding subjects in China are also composed of the government, universities, enterprises and the society. However, generally speaking, the government plays the main responsibility and the main role, while other subjects play a small role and their participation is not high. Figure 1 and Table 1 are the general situation of the financial aid of colleges and universities in recent years.

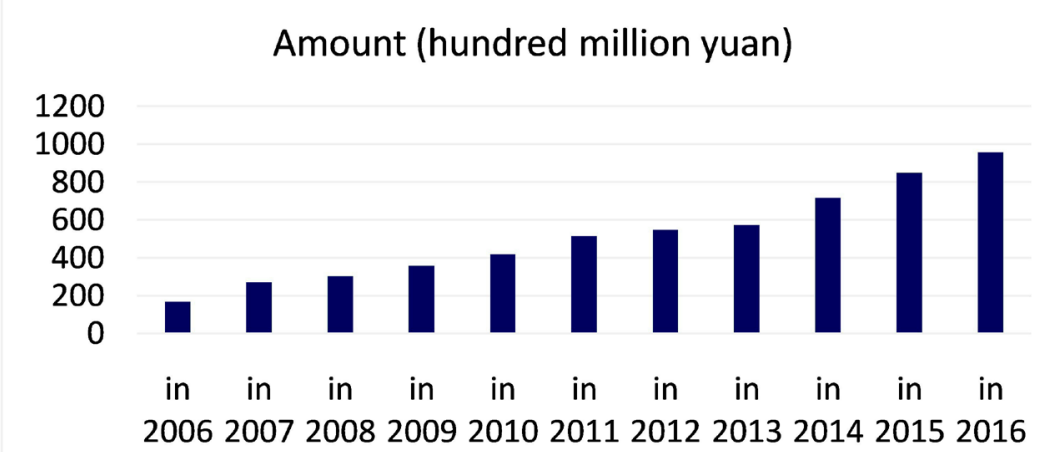

Figure 1. From 2006 to 2016, the amount of student aid provided by Chinese universities.

Table 1. 2012-2016 college student financial aid.

\begin{tabular}{cccccc}
\hline year & 2012 & 2013 & 2014 & 2015 & 2016 \\
\hline $\begin{array}{c}\text { Subsidizing students of ordinary } \\
\text { universities (ten thousand) }\end{array}$ & 3842.7 & 3724.07 & 4064.25 & 4141.58 & 4281.82 \\
$\begin{array}{c}\text { Total amount of university aid (hundred million) } \\
\text { Total financial fund (billion) }\end{array}$ & 547.84 & 574.11 & 716.86 & 847.97 & 955.84 \\
Central finance (billion) & $272.32(49.71 \%)$ & $288.29(50.22 \%)$ & $366.65(51.15 \%)$ & $431.45(50.88 \%)$ & $469.35(49.10 \%)$ \\
Local finance (billion) & & $170.90(29.77 \%)$ & $223.76(31.21 \%)$ & $268.97(31.72 \%)$ & $285.93(29.91 \%)$ \\
Financial institution loan (billion) & $149.03(27.20 \%)$ & $149.84(26.10 \%)$ & $166.99(23.29 \%)$ & $219.86(25.93 \%)$ & $263.21(27.54 \%)$ \\
College income (billion) & $108.69(19.84 \%)$ & $117.74(20.51 \%)$ & $170.88(23.84 \%)$ & $176.67(20.83 \%)$ & $204.74(21.42 \%)$ \\
Social fund (billion) & $17.80(3.25 \%)$ & $18.24(3.18 \%)$ & $12.33(1.72 \%)$ & $19.99(2.36 \%)$ & $18.53(1.94 \%)$ \\
\hline
\end{tabular}

Note: 1) The total financial fund is the sum of central and local finance; 2) Social funds refer to funds donated and subsidized by social organizations, enterprises, institutions and individuals (referred to as social funds); 3) The blanks in the form are the places where no information can be found; (note: the data in the above two figures are compiled from the annual report on the development of financial aid for Chinese students released by the ministry of education of China.) 
2) The funding system works differently. The US funding system operates through two processes: calculating the need for student funding for higher education and designing schemes based on the "financial aid package" concept [5]. The first step refers to the establishment of financial aid office in the United States to work with governments at all levels and universities to calculate the financial aid demand of each student. The calculation of financial aid demand is mainly based on the financial statements and income statements of each family. The second step is to design a "financial aid package" for each student according to the actual situation after calculating the financial aid demand of each student, and using scientific methods and means for students to design several reasonable funding schemes for reference and selection, and feedback this scheme to each university and each student. China's funding system operates in the following ways: first, judge whether the student's family status questionnaire and the materials stamped by the civil affairs department of the place where he/she is registered are complete; Then, class counselors judge the degree of poverty by reading students' reasons for application and family income, etc. Some counselors also assist in conversation or class discussion; Finally, after weighing and comparing, the funding list is determined.

3) The effect of funding. The United States uses scientific means to calculate the funding demand for each student. Students are free to choose the appropriate solution according to their actual situation, and often their funding needs can be met. In addition, such funding operation can reduce the situation of hitchhiking. China is mainly based on family status questionnaire and civil affairs departments of affix one's seal, but family questionnaires can be false, often to civil administration branch stamp also particularly easy, and finally to a lift, some family condition good students enjoy the funding, but those who have the actual needs of the students didn't really enjoy, even some students enjoy a variety of funding. In the process of students' application for financial aid, some counselors will use the form of class discussion and vote, which makes those students who are really in trouble feel embarrassed or unwilling to tell their actual situation in front of everyone, and finally give up the application for financial aid. This form does not take into account students' psychological needs and lacks humanity.

4) Student loan recovery methods are different. In terms of student loan recovery, the loan mechanism of the United States is to repay loans according to the proportion of actual income. Previously, the United States implemented a single installment repayment method, but now the repayment method is more flexible and humane, and the repayment method is available for students to choose. There are four types of loan repayment methods: repayment by installments, repayment by extending the fixed number of years, repayment by the proportion of income and repayment by increasing year by year [6]. China's strict reimbursement deadline specified in the loan recovery mechanism, the interest rate will increase exponentially if the repayment deadline is not met, at the 
same time, the recycling mechanism does not take into account whether students find jobs after graduation, there are a few special cases will give delay the qualification of reimbursement, each students seek job wages or not, at the same interest, in accordance with the prescribed time limit reimbursement.

\section{Inspiration and Reference}

It can be found from the above comparison of the higher education funding system between China and the United States that although China's higher education funding system has formed a five-in-one funding model, there are many deficiencies in the actual operation process, such as relatively single funding subjects and lack of scientific financial statement basis. China can constantly improve the higher education funding system from the following aspects:

\subsection{The Main Body of Funding Is Diversified}

China should encourage enterprises and the society to participate in the higher education funding system, such as: the introduction of corresponding incentive mechanism, to those who actively participate in the support of enterprises to give certain special treatment, the government to give certain political support to these enterprises; should actively help to promote this positive energy of enterprises. The diversification of funding bodies is conducive to reducing the pressure on the government, so that the government has the power to do great things and do good things. Diversification of funding subjects will also help enterprises and the public to enhance their sense of social responsibility, so that the public will know that the government does not take charge of everything, and that every citizen is responsible for social and national affairs.

\subsection{To Formulate Unified Standards and Strengthen the Awareness of Power and Obligation of Civil Affairs Departments Based on Scientific Financial Statements}

So far, the procedures and requirements for applying for financial aid will vary greatly from school to school. The government needs to establish a unified standard for each school to complete the application process according to the standard. At present, our country mainly determines the object of subsidy according to the family situation questionnaire and the local civil affairs department seal certificate. On the one hand, the family situation questionnaire is mainly filled in according to the students' subjective ideas, and there are a lot of falsifications. On the other hand, the questionnaire of family situation can only show the static situation of family income, and it cannot reflect the dynamic change of family income, which is not a scientific basis. Therefore, the financial statement system should be improved. However, the local civil affairs departments fail to realize the relationship between power and responsibility. When they link the power stamped with the responsibility, they will use their power through field investigation. 


\subsection{Develop the "Financial Aid Package" According to the Actual Situation}

On the basis of the financial statements of the scientific, tailored for each student a "package", the "package" can be intuitive feedback out of each of the students the actual demand of fund. Universities can use this "package" to identify who they need to sponsor, students can also according to the "package" to determine the direction of the actual situation.

\subsection{Pay Attention to the Psychological State of Students}

On November 21, 2017, the China student financial aid management center issued a warning: to protect students' personal information and privacy, and make the financial aid work more compliant, more loving and more warm. Family difficulties students feel inferior because of family conditions worse than others, for some students apply for financial aid is a personal privacy, don't want other students know the personal family, If the counselor adopts the method of class discussion and selection, some students will give up the application for financial aid because they feel their privacy is snooped on by others. Therefore, no matter in the qualification review or after determining the target of funding, we should pay attention to students' psychological emotions and conditions, and have a conversation in a way that students are willing to accept.

\subsection{Making Innovations in the Way Student Loans Are Recycled}

China's student loan recovery has a strict recovery date, which is a single installment repayment method. To some extent, it neglects the actual employment situation and ability of students, so many students can only deliberately default. China can introduce the four loan repayment methods of the United States, which are installment repayment, extension repayment, repayment by income ratio and repayment by increasing year by year, so that students can choose the repayment method flexibly according to their personal conditions and make the student loan recovery more humanized.

\subsection{Using Big Data, Accurate Funding}

On September 29, 2017, People's Daily commented that efforts should be made in accurate funding. In order to better improve China's higher education funding system, it is necessary to establish and improve the precise funding system, improve the quantifiable evaluation index system, and then scientifically and effectively assess and accurately determine the target of funding to help every student in need. In order to help every poor student, we can make comprehensive use of big data analysis, determine the amount of financial aid according to the economic development of each region, and provide precise help according to the actual needs of each student, thus achieving three precision: the object of funding, funding amount and timing of funding accurate.

The report of the 19th national congress of the communist party of China puts 
the priority on developing education and ensuring that education meets the people's needs. To achieve this goal, we must take full account of the education of poor students, and the higher education funding system effectively protects the interests of these people. Although China's higher education funding system has a lot of shortcomings, in the future continuous self-criticism, correction and reference process will be able to better development, to achieve this great goal to make an effort.

\section{Conflicts of Interest}

The author declares no conflicts of interest regarding the publication of this paper.

\section{References}

[1] Zhao, T.T. and Ren, Y. (2010) Student Support Policy in American Higher Education-An Interview with Professor Donald Hassle of Indiana University. Journal of Higher Education Research, 2, 10.

[2] Zhang, B. (2017) The Research and Enlightenment of Student Aid Policy in American Universities. Education Science \& Culture, 9, 126.

[3] Wang, M.L. (2013) Comparison and Enlightenment of Student Aid between Chinese and American Universities. Journal of Fujian Radio and Television University, 3,36 .

[4] He, Q.Y. and Lei, W.W. (2013) International Comparison of Higher Education Funding Policies-Focusing on the Comparison between China and the United States. New Curriculum Research, 8, 28.

[5] Li, H. (2010) A Comparative Study of Chinese and American Higher Education Funding Systems. Master's Thesis, Wuhan University, Wuhan.

[6] Zheng, Y.L. (2011) Comparative Analysis and Research on the Financial Aid System of Chinese and American College Students. Journal of Ningxia University (Humanities and Social Sciences), 33, 190. 